\title{
Single-nucleotide polymorphisms and haplotypes in the interleukin-33 gene are associated with a risk of allergic rhinitis in the Chinese population
}

\author{
HE RAN $^{1 *}$, HUA XIAO $^{2 *}$, XING ZHOU $^{3}$, LIJUN GUO $^{2}$ and SHUANG LU ${ }^{2}$ \\ ${ }^{1}$ Department of Otolaryngology Head and Neck Surgery, The Second Hospital of Jingzhou, Jingzhou, Hubei 434000; \\ ${ }^{2}$ Hubei College of Chinese Medicine, Jingzhou, Hubei 434020; ${ }^{3}$ Department of Otolaryngology Head and Neck Surgery, \\ Shishou People's Hospital, Jingzhou, Hubei 434400, P.R. China
}

Received February 29, 2020; Accepted July 23, 2020

DOI: $10.3892 /$ etm.2020.9232

\begin{abstract}
Allergic rhinitis (AR) is a common upper airway disease attributed to a variety of risk factors, such as environmental exposures and genetic susceptibility. The commonly observed comorbidity of asthma and AR in the clinic suggests the presence of shared genetic risk factors and biological mechanisms between these diseases. Interleukin (IL)-33 has been indicated to be an important factor driving asthma susceptibility and pathogenesis using both genome-wide association studies and functional studies in model animals. Although previous studies have reported the putative association of this gene with AR, evidence for the association of genetic variations of $I L-33$ with the disease is still missing. To examine whether variations in the $I L-33$ gene confer a genetic risk of AR, a total of 769 patients with AR and 769 age- and sex-matched healthy controls were recruited among Han Chinese residents in the Hubei province, and 14 single-nucleotide polymorphisms (SNPs) spanning the $I L-33$ gene were examined for their association with the risk of AR. The results indicated that five SNPs, which were in a moderate linkage disequilibrium and were located in the 5'-flanking region of $I L-33$, exhibited significant associations with the risk of AR, and these associations were additionally supported by genotypic and haplotypic analyses. Notably, three of the five $I L-33$ SNPs have been previously reported to exhibit genome-wide associations with asthma, and their alleles were also revealed to confer an increased risk of AR in the present study. In summary, the results of the current study suggested that certain variations in the $I L-33$ gene represent a potential
\end{abstract}

Correspondence to: Ms. Hua Xiao, Hubei College of Chinese Medicine, 87 Xueyuan Lu Street, Jingzhou, Hubei 434020, P.R. China E-mail: xh2537@163.com

*Contributed equally

Key words: allergic rhinitis, asthma, interleukin-33, single-nucleotide polymorphisms, Chinese population risk for AR, and indicated a shared genetic basis between AR and asthma.

\section{Introduction}

Allergic rhinitis (AR) is a common upper airway disease, which is characterized by sneezing, rhinorrhea and obstruction of the nasal passages (1). A previous study revealed that AR was mediated by immunoglobulin (Ig)E-induced upper airway inflammation, which is commonly triggered by exposure to allergens (1). AR has been indicated to coexist with other allergic and/or airway conditions, such as asthma, rhinosinusitis, nasal polyps and lower airway infection, among others (2-4). AR is highly prevalent with an incidence rate of $10-20 \%$ worldwide $(1,5)$, which has rapidly increased along with industrialization (6). Therefore, AR is considered a major and emerging public health concern, especially in developed countries $(6,7)$. The prevalence of AR in urban China has substantially increased in the past few years (from 2005 to 2011) (8). An epidemiological study has indicated that the overall prevalence of AR in adults in major cities across mainland China has increased from $11.1 \%$ in 2005 to $17.6 \%$ in 2011, and patients with AR have been revealed to be more susceptible to allergic complications compared with the general population (8). Therefore, subjects diagnosed with AR have been indicated to experience a reduction in their quality of life, although not always severe (9). However, AR cannot be completely treated, which poses a substantial socioeconomic burden (1).

Previous studies have revealed that environmental stimuli serve pivotal roles in the allergic airway responses that are essential for the initiation and exacerbation of AR $(10,11)$. Nevertheless, a potent genetic component has been also associated with this disease (12). The heritability of AR has been estimated to be $>65 \%(13,14)$. A number of studies have suggested that sequence polymorphisms in multiple genes and regions are associated with an increased risk of AR (15-22), although another study has reported the poor reproducibility of single-nucleotide polymorphism (SNP) associations with this disease (23). Nevertheless, certain genetic variations that have been associated with AR support the hypothesized 
pathophysiology of this disease (24). Therefore, genetic and physiological investigations cross-validate the putative mechanisms of AR, providing essential insights into its pathogenesis, treatment and prevention (25).

A previous study has suggested that type $2 \mathrm{~T}$ helper (Th2) cell-mediated inflammatory responses against environmental stimuli, including pollutants and allergens, contributed in AR pathophysiology (26). According to the classical model for allergic airway diseases, including AR and allergens, which are presented by antigen-presenting cells, result in the activation and expansion of Th2 cells. These Th2 cells have been indicated to subsequently produce Th2 cytokines, such as interleukin (IL)-4, IL-5 and IL-13, which drive IgE antibody production and promote the proliferation and differentiation of multiple effector cells, for example mast cells, eosinophils and basophils $(27,28)$. This results in the secretion of multiple key inflammatory mediators, such as leukotriene and histamine (29-31). In addition to these well-characterized Th2 cytokines, other mediators that are primarily released by epithelial cells, which constitute the first line of defense against environmental stimuli, have also attracted attention owing to their determinant roles in initiating the inflammatory responses. For example, epithelium-derived IL-33 has been indicated to induce allergic airway inflammation $(32,33)$. Previous studies have also reported that during allergen-driven inflammation, IL-33 was expressed by a variety of immune cells, including important immune cell types such as eosinophils $(32,33)$.

IL-33 is a member of the IL-1 family of cytokines $(34,35)$. The role of IL-33 in bronchial asthma has been extensively studied $(34,35)$. SNPs in the genes encoding $I L-33$ and its receptor $S T 2$, which is also referred to as $I L 1$ receptor-like $(R L) 1$, have been indicated to be associated with allergic asthma and atopic dermatitis (35-37). In addition, clinical studies have demonstrated that the serum levels of IL-33 and the soluble form of ST2 (sST2) were indicators of asthma progression and exacerbation $(38,39)$. Functional studies have additionally verified the impact of IL-33 and ST2 on allergic airway inflammation. For example, IL-33 has been indicated to induce the production of $\mathrm{Th} 2$ cytokines by polarized $\mathrm{Th} 2$ cells in vitro (40), and increase the expression of Th2 cytokines and the serum levels of IgE in vivo (40). In murine models of allergic airway inflammation, allergen exposure has been revealed to increase the endogenous levels of ST2 and Th2-mediated airway inflammation (41), while blockade of ST2 using a recombinant IgG fusion protein has been indicated to inhibit the allergic inflammation $(42,43)$. Notably, ST2 has been indicated to be highly expressed on mast cells, except for Th2 cells, $(42,44,45)$, which suggests a potential direct impact of IL-33 on a number of hypersensitive and allergic reactions that are mediated by these cells.

Previous studies have examined the potential association of IL-33 with AR, as IL-33 has been indicated to exhibit a well-characterized regulatory impact on the initiation and exacerbation of allergic airway responses (46-48). In patients with intermittent $A R$ who are sensitive to trees and/or grass pollens, serum IL-33 has been revealed to be increased compared with normal controls and positively correlate with disease severity (49). The serum levels of IL-33 have also been reported to be higher in patients with Japanese cedar (JC) pollinosis compared with normal controls (50), and two IL-33 SNPs have been associated with the disease (50). Notably, IL-33 in the serum of patients with AR can be decreased following immunotherapy (51). Intranasal administration of anti-tumor necrosis factor- $\alpha$ IgY has been indicated to reduce both IL-33 and ovalbumin-specific IgE antibodies in the serum and nasal lavage fluids of patients (52). Although IL-33 is not always detectable in serum, increased levels of IL-33 in sinus mucosa have also been reported in patients with $\mathrm{JC}$ pollinosis and house dust mite (HDM)-sensitized AR (53). A previous study has demonstrated that an anti-IL-33 antibody exhibited a therapeutic potential in experimental AR (54). Moreover, IL-33 receptor ST2 has been indicated to be highly expressed in the nasal epithelium of patients with AR or chronic rhinosinusitis (55-57), and the concentration of sST2 in the nasal lavage fluids of patients with AR have been revealed to increase when patients experience pollen-induced allergic reactions (58). Taken together, these data suggest that IL-33 likely facilitates the pathogenesis of AR. Therefore, additional studies on this cytokine may provide novel insights on potential preventive strategies against AR.

As aforementioned, the prevalence of AR has increased in recent years in the Chinese population; however little is known about the susceptibility factors to AR, especially the genetic basis, in this ethnic group. Therefore, the aim of the present study was to perform genetic analyses of the $I L-33$ variations in the Han Chinese population to reveal whether variations in this gene confer an inheritable risk of AR.

\section{Materials and methods}

Subjects. A total of 769 patients with AR (453 men and 316 women) aged between 10 and 65 years (mean \pm standard deviation, 37.74 \pm 16.52 ) were recruited between January 2014 and July 2019. The diagnosis of AR was performed following the criteria of Allergic Rhinitis and its Impact on Asthma (1). Subjects presenting $>$ two common symptoms of AR (for example nasal congestion, rhinorrhea, nasal itching and sneezing) for $>4$ days/week for at least 3 weeks during the past 12 months were diagnosed with AR. All patients received antihistaminic and steroids at The Second Hospital of Jingzhou and Shishou People's Hospital (Jingzhou, China). Specific allergens as potential cause of AR were determined for each patient via skin prick tests (SPT; Allergopharma GmbH \& Co. KG) in accordance with the recommendations by the Subcommittee on Allergen Standardization and Skin Tests of the European Academy of Allergy and Clinical Immunology (59). A total of 18 inhaled allergens, including HDM, grass, tree, mold, food and weed panel allergens, were examined. The presence of a wheal $\geq$ one half of the diameter of the histamine control and $>3 \mathrm{~mm}$ of the negative control was defined positive in the SPT. Patients with any other systemic diseases were excluded from the study.

A total of 769 healthy volunteers ( 442 men and 327 women) aged between 10 and 65 years (mean \pm standard deviation, $37.01 \pm 15.94$ ) that tested negative for allergens in the skin prick tests were recruited as control subjects in the current study. The controls were also recruited at The Second Hospital of Jingzhou and Shishou People's Hospital (Jingzhou, China) between January 2014 and July 2019. In addition, the control 
subjects did not exhibit any clinical diagnosis or family history of allergy, and did not experience an upper respiratory tract infection within the last 4 weeks prior to the study. All patients and controls were Han Chinese.

SNP selection. SNPs were selected based on previous studies and the genotype data from the 1,000 Genomes Project (60). Based on the high comorbidity rate of AR and asthma, genome-wide association studies (GWAS) on asthma were firstly screened to select genome-wide significant variants spanning $I L-33$. Briefly, four SNPs (rs928413, rs9775039, rs992969 and rs2381416) in IL-33 have been indicated to exhibit genome-wide significant associations with asthma in previous GWAS on European and Asian populations (24,61-64). According to the 1,000 Genomes Project, three $I L-33$ SNPs (rs928413, rs992969 and rs2381416) have been indicated to be polymorphic in the Han Chinese population, and therefore were selected in the present study. The aforementioned study in subjects with JC pollinosis was also reviewed (50), and two additional SNPs that have been associated with this disease were selected (rs1929992 and rs10975519; Fig. 1). The linkage disequilibrium (LD) pattern of $I L-33$ in the Han Chinese population was subsequently examined based on data from the 1,000 Genomes Project, and nine representative tagging SNPs (rs1475658, rs10815374, rs1891385, rs16924144, rs10435816, rs16924159, rs16924161, rs117414011 and rs78100995) spanning the $I L-33$ gene were selected (Fig. 1). In summary, a total of 14 SNPs (Table I) were selected for subsequent investigation in the current study.

SNP genotyping. Saliva was collected from the participants, and genomic DNA was extracted according to the manufacturer's protocol (MagMAX gDNA Saliva Isolation Kit; Thermo Fisher Scientific, Inc.). The extracted DNA was dissolved in $50 \mathrm{ml}$ Tris-EDTA buffer (10 mM Tris, $\mathrm{pH}$ 7.8; 1 mM EDTA). The concentration of the DNA samples was quantified via measuring the optical density at $260 \mathrm{~nm}$ using NanoDrop. A multiplex PCR was performed to simultaneously amplify multiple SNPs in one reaction in 96-well plates, and each well contained $20 \mathrm{ng}$ genomic DNA, $10 \mathrm{mmol} / 1$ primers (the primer sequences are presented in Table SI), $2 \mu \mathrm{l}$ dNTP, $2 \mu \mathrm{l}$ 10X PCR buffer, $1 \mu \mathrm{l} 25 \mathrm{mmol} / 1 \mathrm{MgCl}_{2}$ and 0.4 units Taq polymerase (Takara Biotechnology Co., Ltd.). The multiplex PCR reaction was conducted on an ABI 9700 cycler (Applied Biosystems; Thermo Fisher Scientific, Inc.) using the following thermocycling conditions: Denaturation for $5 \mathrm{~min}$ at $95^{\circ} \mathrm{C} ; 40$ cycles of $30 \mathrm{sec}$ at $95^{\circ} \mathrm{C}, 30 \mathrm{sec}$ at $60^{\circ} \mathrm{C}$ and $30 \mathrm{sec}$ at $72^{\circ} \mathrm{C}$; and extension for $10 \mathrm{~min}$ at $72^{\circ} \mathrm{C}$. The PCR products were subsequently used to genotype candidate SNPs with the SNaPshot method. In brief, the PCR products were purified via shrimp alkaline phosphatase (cat. no. M0371L; New England Biolabs) and exonuclease I (cat. no. M0293L; BioLabs) treatment at $37^{\circ} \mathrm{C}$ for $1 \mathrm{~h}$. Specifically designed SNaPshot primers (the primer sequences are presented in Table SII) were used to amplify the SNP target sites for one base extension using SNaPshot Multiplex Ready Reaction Mix (cat. no. 4323166; Applied Biosystems; Thermo Fisher Scientific, Inc.), following which the reaction was terminated and the products were loaded on an ABI 3730 automated sequencer (Applied Biosystems; Thermo Fisher Scientific, Inc.). The SNP genotype calling results were automatically retrieved using GeneMarker version 2.2.0

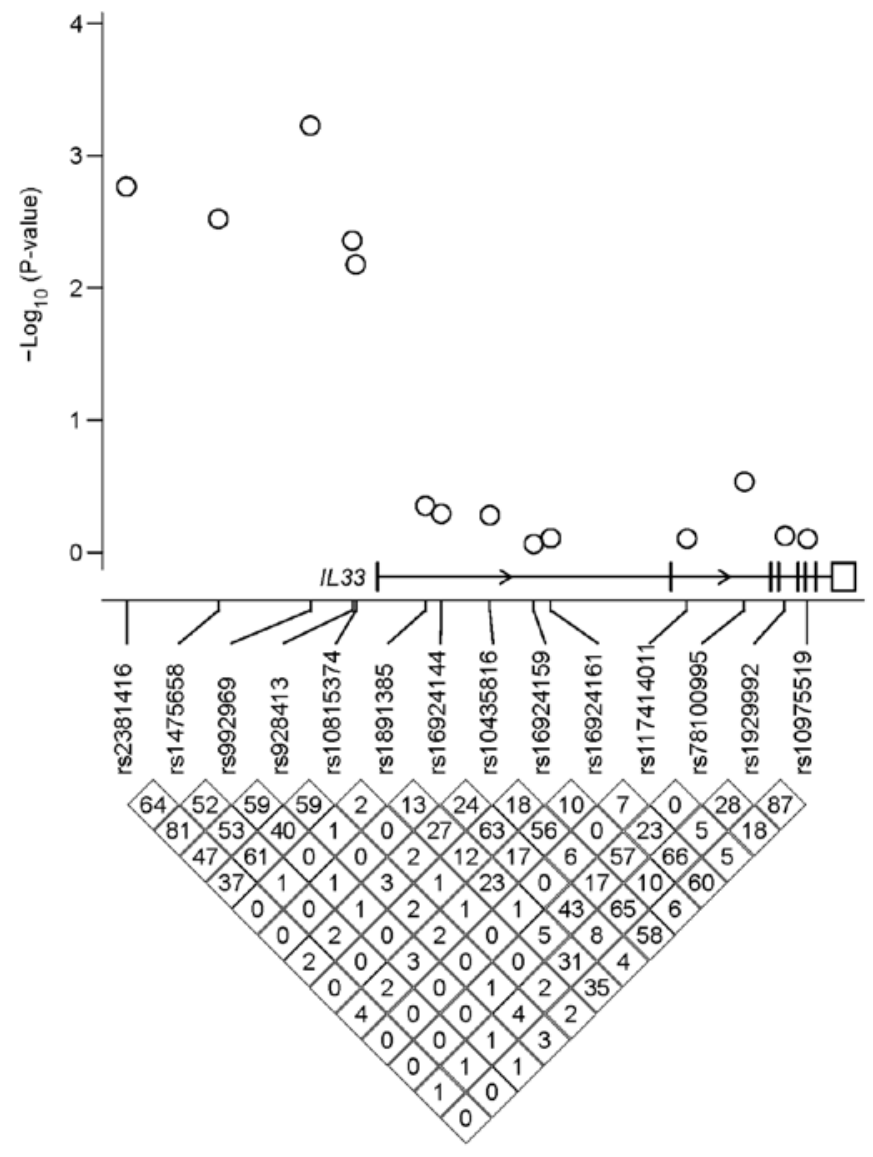

Figure 1. Association of SNPs spanning the $I L-33$ gene with the risk of allergic rhinitis. The linkage disequilibrium map of the indicated SNPs in Han Chinese individuals from the 1,000 Genomes Project is presented. SNP, single-nucleotide polymorphism; IL, interleukin.

software (SoftGenetics) and were manually verified. All genotypes were called blind to sample identity and affection status and were independently reviewed and confirmed by two authors. A total of $5 \%$ of the samples were randomly selected for re-analysis to ensure $100 \%$ concordance.

Statistical analyses. Haploview software (version 4.1; Broad Institute of Massachusetts Institute of Technology and Harvard) (65) and the online program SHEsis (http://analysis. bio-x.cn/myAnalysis.php) $(66,67)$ were used to calculate the Hardy-Weinberg equilibrium (HWE) of each SNP in cases and controls, and the LD between paired SNPs was defined using the $\mathrm{r}^{2}$ algorithm. SHEsis was also used to compare the allelic and genotypic distributions of each SNP between cases and controls, and Pearson's $\chi^{2}$ test was applied to calculate the $\mathrm{P}$-values, odds ratios (ORs) and $95 \%$ confidence intervals $(66,67)$. Haplotype frequencies and association signals were estimated with the online program SHEsis using the $\chi^{2}$ test $(66,67)$. The haplotypes with a frequency $<0.005$ in both cases and controls were discarded, and nine haplotypes remained for subsequent analyses.

\section{Results}

Demographics of the participants. No significant differences were observed between cases and controls in terms of their 
Table I. HWE and genotypic association analyses of 14 interleukin-33 SNPs with the risk of allergic rhinitis.

\begin{tabular}{|c|c|c|c|c|c|}
\hline \multirow{2}{*}{$\begin{array}{l}\text { SNP } \\
\text { rs2381416 }\end{array}$} & \multicolumn{3}{|c|}{ Genotype, n (frequency) } & \multirow[t]{2}{*}{ HWE } & \multirow[t]{2}{*}{ P-value } \\
\hline & $\mathrm{A} / \mathrm{A}$ & $\mathrm{A} / \mathrm{C}$ & $\mathrm{C} / \mathrm{C}$ & & \\
\hline Cases & $674(0.880)$ & $87(0.114)$ & $5(0.007)$ & 0.24 & 0.009 \\
\hline Controls & $710(0.926)$ & $55(0.072)$ & $2(0.003)$ & 0.40 & \\
\hline rs 1475658 & $\mathrm{~A} / \mathrm{A}$ & $\mathrm{A} / \mathrm{T}$ & $\mathrm{T} / \mathrm{T}$ & & \\
\hline Cases & $627(0.826)$ & $125(0.165)$ & $7(0.009)$ & 0.78 & 0.013 \\
\hline Controls & $665(0.880)$ & $87(0.115)$ & $4(0.005)$ & 0.53 & \\
\hline rs992969 & $\mathrm{A} / \mathrm{A}$ & $\mathrm{A} / \mathrm{G}$ & $\mathrm{G} / \mathrm{G}$ & & \\
\hline Cases & $3(0.004)$ & $77(0.100)$ & $689(0.896)$ & 0.59 & 0.0023 \\
\hline Controls & $2(0.003)$ & $41(0.053)$ & $726(0.944)$ & 0.09 & \\
\hline rs928413 & $\mathrm{A} / \mathrm{A}$ & $\mathrm{A} / \mathrm{G}$ & $\mathrm{G} / \mathrm{G}$ & & \\
\hline Cases & $651(0.849)$ & $114(0.149)$ & $2(0.003)$ & 0.20 & 0.0012 \\
\hline Controls & $690(0.903)$ & $69(0.090)$ & $5(0.007)$ & 0.03 & \\
\hline rs10815374 & $\mathrm{A} / \mathrm{A}$ & $\mathrm{A} / \mathrm{G}$ & $\mathrm{G} / \mathrm{G}$ & & \\
\hline Cases & $5(0.007)$ & $102(0.133)$ & $662(0.861)$ & 0.62 & 0.02 \\
\hline Controls & $4(0.005)$ & $68(0.088)$ & $697(0.906)$ & 0.10 & \\
\hline rs1891385 & $\mathrm{A} / \mathrm{A}$ & $\mathrm{A} / \mathrm{C}$ & $\mathrm{C} / \mathrm{C}$ & & \\
\hline Cases & $401(0.533)$ & $306(0.407)$ & $45(0.060)$ & 0.18 & 0.74 \\
\hline Controls & $383(0.515)$ & $312(0.419)$ & $49(0.066)$ & 0.17 & \\
\hline rs16924144 & $\mathrm{C} / \mathrm{C}$ & $\mathrm{C} / \mathrm{T}$ & $\mathrm{T} / \mathrm{T}$ & & \\
\hline Cases & $91(0.118)$ & $346(0.450)$ & $332(0.432)$ & 0.95 & 0.2 \\
\hline Controls & $71(0.092)$ & $369(0.480)$ & $329(0.428)$ & 0.02 & \\
\hline rs10435816 & $\mathrm{A} / \mathrm{A}$ & $\mathrm{A} / \mathrm{G}$ & $\mathrm{G} / \mathrm{G}$ & & \\
\hline Cases & $273(0.355)$ & $377(0.490)$ & $119(0.155)$ & 0.55 & 0.81 \\
\hline Controls & $282(0.367)$ & $376(0.489)$ & $111(0.144)$ & 0.43 & \\
\hline rs16924159 & $\mathrm{A} / \mathrm{A}$ & $\mathrm{A} / \mathrm{G}$ & $\mathrm{G} / \mathrm{G}$ & & \\
\hline Cases & $70(0.091)$ & $333(0.433)$ & $366(0.476)$ & 0.64 & 0.98 \\
\hline Controls & $68(0.088)$ & $333(0.433)$ & $368(0.479)$ & 0.55 & \\
\hline rs16924161 & $\mathrm{C} / \mathrm{C}$ & $\mathrm{C} / \mathrm{T}$ & $\mathrm{T} / \mathrm{T}$ & & \\
\hline Cases & $98(0.127)$ & $351(0.456)$ & $320(0.416)$ & 0.91 & 0.97 \\
\hline Controls & $101(0.131)$ & $352(0.458)$ & $316(0.411)$ & 0.85 & \\
\hline rs117414011 & $\mathrm{C} / \mathrm{C}$ & $\mathrm{C} / \mathrm{T}$ & $\mathrm{T} / \mathrm{T}$ & & \\
\hline Cases & $3(0.004)$ & $67(0.087)$ & 699 (0.909) & 0.31 & 0.60 \\
\hline Controls & $1(0.001)$ & $68(0.088)$ & $700(0.910)$ & 0.62 & \\
\hline rs78100995 & $\mathrm{C} / \mathrm{C}$ & $\mathrm{C} / \mathrm{G}$ & $\mathrm{G} / \mathrm{G}$ & & \\
\hline Cases & $412(0.537)$ & $293(0.382)$ & $62(0.081)$ & 0.33 & 0.54 \\
\hline Controls & $428(0.557)$ & $288(0.375)$ & $52(0.068)$ & 0.71 & \\
\hline rs1929992 & $\mathrm{C} / \mathrm{C}$ & $\mathrm{C} / \mathrm{T}$ & $\mathrm{T} / \mathrm{T}$ & & \\
\hline Cases & $233(0.304)$ & $385(0.502)$ & $149(0.194)$ & 0.66 & 0.90 \\
\hline Controls & $240(0.314)$ & $376(0.492)$ & $148(0.194)$ & 0.97 & \\
\hline rs10975519 & $\mathrm{C} / \mathrm{C}$ & $\mathrm{C} / \mathrm{T}$ & $\mathrm{T} / \mathrm{T}$ & & \\
\hline Cases & $168(0.218)$ & $388(0.505)$ & $213(0.277)$ & 0.73 & 0.97 \\
\hline Controls & $165(0.215)$ & $387(0.503)$ & $217(0.282)$ & 0.76 & \\
\hline
\end{tabular}

SNP, single-nucleotide polymorphism; HWE, Hardy-Weinberg equilibrium.

mean age $(\mathrm{P}=0.38)$ and sex distribution $(\mathrm{P}=0.29)$. According to the SPT results of 769 patients with AR, 352 (45.8\%) were sensitized to HDM, 147 (19.1\%) were sensitized to tree pollen and 270 (35.1\%) were sensitized to multiple allergens (data not shown).
$L D$ of the $I L-33$ gene. A total of 14 SNPs in $I L-33$, with a frequency $>0.01$, were selected to examine their associations with AR. Their locations within or close to the $I L-33$ gene and the LD map in the Han Chinese population are presented 
Table II. Allelic association analysis of 14 interleukin-33 SNPs with the risk of allergic rhinitis.

\begin{tabular}{|c|c|c|c|c|c|c|c|c|}
\hline \multirow[b]{2}{*}{ SNP } & \multirow[b]{2}{*}{ Position } & \multirow[b]{2}{*}{$\mathrm{A} 1 / \mathrm{A} 2$} & \multicolumn{2}{|c|}{ Frequency of A1 } & \multirow[b]{2}{*}{$\chi^{2}$-value } & \multirow[b]{2}{*}{ P-value } & \multirow[b]{2}{*}{ OR } & \multirow[b]{2}{*}{$95 \% \mathrm{CI}$} \\
\hline & & & Cases & Controls & & & & \\
\hline rs2381416 & $9: 6193455$ & $\mathrm{C} / \mathrm{A}$ & 0.0633 & 0.0385 & 9.805 & 0.0017 & 1.69 & $1.21-2.35$ \\
\hline rs1475658 & $9: 6201574$ & $\mathrm{~T} / \mathrm{A}$ & 0.0916 & 0.0628 & 8.778 & 0.0030 & 1.50 & $1.15-1.97$ \\
\hline rs992969 & 9:6209697 & $\mathrm{A} / \mathrm{G}$ & 0.0540 & 0.0293 & 11.770 & 0.0006 & 1.89 & $1.31-2.74$ \\
\hline rs928413 & $9: 6213387$ & $\mathrm{G} / \mathrm{A}$ & 0.0769 & 0.0517 & 8.089 & 0.0045 & 1.53 & $1.14-2.05$ \\
\hline rs10815374 & $9: 6213705$ & $\mathrm{~A} / \mathrm{G}$ & 0.0728 & 0.0494 & 7.342 & 0.0067 & 1.51 & $1.12-2.04$ \\
\hline rs1891385 & $9: 6219845$ & $\mathrm{C} / \mathrm{A}$ & 0.263 & 0.276 & 0.569 & 0.45 & 0.94 & $0.80-1.10$ \\
\hline rs16924144 & $9: 6221246$ & $\mathrm{C} / \mathrm{T}$ & 0.343 & 0.332 & 0.420 & 0.52 & 1.05 & $0.91-1.22$ \\
\hline rs10435816 & $9: 6225535$ & $\mathrm{G} / \mathrm{A}$ & 0.400 & 0.389 & 0.393 & 0.53 & 1.05 & $0.91-1.21$ \\
\hline rs16924159 & $9: 6229417$ & $\mathrm{~A} / \mathrm{G}$ & 0.308 & 0.305 & 0.024 & 0.88 & 1.01 & $0.87-1.18$ \\
\hline rs16924161 & $9: 6230912$ & $\mathrm{C} / \mathrm{T}$ & 0.356 & 0.360 & 0.069 & 0.79 & 0.98 & $0.85-1.14$ \\
\hline rs117414011 & $9: 6242939$ & $\mathrm{C} / \mathrm{T}$ & 0.0475 & 0.0455 & 0.066 & 0.80 & 1.05 & $0.75-1.46$ \\
\hline rs78100995 & $9: 6248007$ & $\mathrm{G} / \mathrm{C}$ & 0.272 & 0.255 & 1.094 & 0.30 & 1.09 & $0.93-1.28$ \\
\hline rs1929992 & $9: 6251588$ & $\mathrm{~T} / \mathrm{C}$ & 0.445 & 0.440 & 0.092 & 0.76 & 1.02 & $0.89-1.18$ \\
\hline rs10975519 & $9: 6253571$ & $\mathrm{C} / \mathrm{T}$ & 0.471 & 0.466 & 0.064 & 0.80 & 1.02 & $0.88-1.17$ \\
\hline
\end{tabular}

SNP, single-nucleotide polymorphism; A1/A2, allele 1/allele 2; OR, odds ratio; CI, confidence interval.

in Fig. 1. All these SNPs were biallelic with minor allele frequency $(\mathrm{MAF})>1 \%$. The asthma GWAS risk SNPs (rs928413, rs992969 and rs2381416) were localized in the 5'-flanking region of the $I L-33$ gene, one SNP (rs10975519) represented a synonymous substitution (Tyr163Tyr) in an $I L-33$ exon and the remaining SNPs were localized in the intronic or intergenic regions. A pairwise LD among the $14 I L-33$ SNPs was constructed using genotype data of Han Chinese individuals $(\mathrm{n}=208)$, which were obtained from the 1,000 Genomes Project (Fig. 1).

Association of polymorphisms in the IL-33 gene with the risk of $A R$. The call rate for the SNPs was $>99 \%$, and all SNPs were in HWE in both patients with AR and healthy controls (HWE P>0.01; Table I). To examine whether SNPs in the $I L-33$ gene exhibited an association with the risk of AR, both the allelic and genotypic frequencies of the SNPs were compared between cases and controls. The analysis of allele frequencies revealed that five SNPs in the 5'-flanking region of $I L-33$ were significantly associated with the risk of AR, and the minor alleles of all five SNPs exhibited significantly increased frequencies in patients with AR compared with controls (rs2381416, $\mathrm{P}=0.0017$, $\mathrm{OR}=1.690$; rs1475658, $\mathrm{P}=0.003, \mathrm{OR}=1.50$; rs992969, $\mathrm{P}=0.0006, \mathrm{OR}=1.89$; rs928413, $\mathrm{P}=0.0045, \mathrm{OR}=1.53 ; \mathrm{rs} 10815374, \mathrm{P}=0.0067, \mathrm{OR}=1.51$; Table II). These five SNPs exhibited a moderate pairwise LD in the Han Chinese population (Fig. 1), and notably, three of them (rs928413, rs992969 and rs2381416) have previously been indicated to be associated with asthma $(61,62,64)$, with their asthma risk alleles being the same as their AR risk alleles, as revealed in the present study. These results verified the genetic link between AR and asthma in the $I L-33$ locus. However, the other nine SNPs in $I L-33$ did not exhibit an association with AR in the current study (Table II). The genotypic analyses of 14 SNPs presented similar results to the allelic analyses (Table I). The LD maps of the $14 I L-33$ SNPs in the Han Chinese case and control samples were constructed, and it was indicated that the LD patterns of cases and controls were similar (Fig. 2). The LD map that was constructed using genotype data from the 1,000 Genomes Project was also indicated to be similar to the LD maps of the cases and controls of the current study (Fig. 1).

Association of haplotypes in the IL-33 gene with the risk of $A R$. As all five SNPs in the 5'-flanking region of $I L-33$ exhibited a significant association with the risk of AR, the association of their haplotypes with the risk of AR was subsequently examined. A protective haplotype that exhibited a significant association with AR was identified (A-A-G-A-G; $\mathrm{P}=0.0001$; Table III). This haplotype contained the protective alleles of all five SNPs, and its frequency was significantly lower in AR cases compared with controls (frequency $=0.884$ in cases vs. 0.925 in controls; $\mathrm{P}=0.0001 ; \mathrm{OR}=0.61$ ). The minor allele frequencies of these five SNPs in the Han Chinese population were relatively low (MAF $<0.1$; Table II), and the frequency of their haplotypes was even lower compared with MAFs (Table III). Nevertheless, two minor haplotypes exhibited a significant association with increased risk of AR in the present study (C-T-A-G-A frequency $=0.041$ in cases vs. 0.026 in controls, $\mathrm{P}=0.023, \mathrm{OR}=1.60$; $\mathrm{C}-\mathrm{T}-\mathrm{A}-\mathrm{A}-\mathrm{G}$ frequency, 0.009 in cases vs. 0.000 in controls, $\mathrm{P}=0.00028$ ). Global analysis also indicated a significant association of these haplotypes with the risk of AR (global $\mathrm{P}=0.00064)$. Collectively, the haplotype analysis additionally demonstrated that $I L-33$ may harbor risk variants for AR.

\section{Discussion}

Allergic rhinitis (AR) is a common allergic disease exhibiting important comorbidity with a number of atopic diseases, for 
Table III. Haplotypic association analysis of five $I L-33$ SNPs (rs2381416, rs1475658, rs992969, rs928413 and rs 10815374) with the risk of allergic rhinitis.

\begin{tabular}{|c|c|c|c|c|c|c|}
\hline Haplotype & Case, frequency & Control, frequency & $\chi^{2}$ value & P-value & OR & $95 \% \mathrm{CI}$ \\
\hline C-T-A-G-A & 0.041 & 0.026 & 5.180 & 0.0230 & 1.60 & $1.06-2.40$ \\
\hline C-T-A-A-G & 0.009 & 0.000 & 13.210 & 0.0003 & - & - \\
\hline C-T-A-G-G & 0.005 & 0.003 & 0.570 & 0.4500 & 1.54 & $0.50-4.74$ \\
\hline C-T-G-A-G & 0.009 & 0.009 & 0.047 & 0.8300 & 0.92 & $0.43-1.96$ \\
\hline A-T-G-G-A & 0.012 & 0.013 & 0.007 & 0.9400 & 0.97 & $0.51-1.86$ \\
\hline A-A-G-A-A & 0.006 & 0.003 & 1.210 & 0.2700 & 1.82 & $0.61-5.42$ \\
\hline A-T-G-A-A & 0.013 & 0.007 & 2.700 & 0.1000 & 1.84 & $0.88-3.83$ \\
\hline A-A-G-G-G & 0.018 & 0.010 & 3.230 & 0.0700 & 1.78 & $0.94-3.35$ \\
\hline A-A-G-A-G & 0.884 & 0.925 & 15.000 & 0.0001 & 0.61 & $0.47-0.79$ \\
\hline
\end{tabular}

Global $\chi^{2}=27.2$; degree of freedom=8; $\mathrm{P}=0.00064$. OR, odds ratio; CI, confidence interval.
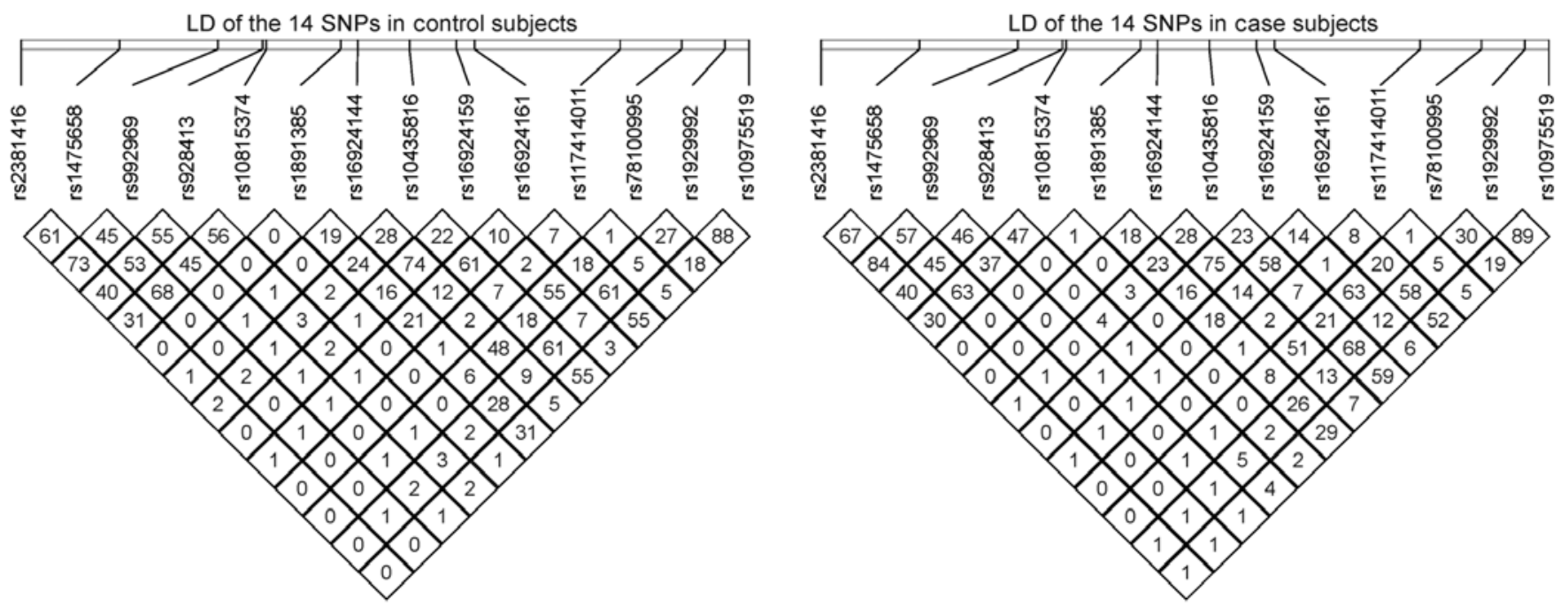

Figure 2. LD maps of $14 I L-33$ SNPs examined in case and control subjects in the present study. The LD maps were generated using Haploview software. SNP, single-nucleotide polymorphism; LD, linkage disequilibrium; IL, interleukin.

example allergic asthma. Although Th2-mediated allergic inflammation has been indicated to facilitate AR pathogenesis, the associated genetic components remain to be fully determined (1). As $>80 \%$ of patients with asthma exhibit rhinitis, and $10-40 \%$ of patients with rhinitis develop asthma, these two diseases are considered to share risk factors and mechanisms (1). Therefore, it is of interest to examine the association between the GWAS risk loci of asthma and AR. IL-33 has been highlighted as an important initiating factor for allergic asthma, and a recent study on whole blood gene expression profiles has revealed a consistent overexpression of the ILIRLI gene, which encodes IL-33 receptor ST2, in patients diagnosed with multiple morbidities for asthma, dermatitis and rhinitis compared with normal controls (68). Therefore, the present study aimed to explore whether polymorphisms in $I L-33$ also affect the susceptibility to AR. Using the SNaPshot method, the current study indicated that SNPs in the $I L-33$ gene, which have been previously associated with asthma $(61,62,64)$, were also associated with AR. This observation supported the shared pathological mechanism between asthma and AR, and provided insights into inflammatory responses associated with AR (69). Previous studies have also reported that asthma susceptibility loci exhibited an association with AR, and several other risk variants have also been highlighted conferring a risk of both asthma and AR (70-73).

The SNPs that were significantly associated with AR in the present study were localized in the promoter region of $I L-33$, and may have potential regulatory impact on this gene. For example, the A-allele of rs992969, which is associated with an increased risk of AR in the present study, was also significantly associated with higher $I L-33$ expression in bronchial epithelial cells $\left(\mathrm{P}=1.3 \times 10^{-6}\right)$ in a previous study (74). A recent study has indicated that the A-allele of rs 992969 was significantly associated with a higher mRNA level of $I L-33$ in bronchial brushes $\left(\mathrm{P}=8.3 \times 10^{-12}\right)(75)$. In addition, a functional study has revealed that the G-allele of rs928413 was associated with higher $I L-33$ promoter activity compared with the A-allele in lung cancer cells, and the G-allele of rs928413 included a binding site for cyclic AMP-responsive element-binding protein 1 , which is likely an activator of $I L-33$ 
transcription in the presence of this allele (76). These studies have demonstrated the potential regulatory effects of these SNPs on the transcription of IL-33.

Although a number of atopic conditions are considered to arise from altered Th2 immune responses against environmental allergens $(77,78)$, the involvement of IL-33 in this process has attracted attention in recent years. In addition to targeting altered $\mathrm{Th} 2 \mathrm{immune}$ responses and their downstream effectors, it has been recognized that the successful prevention of allergic airway diseases is important to alleviate public health and economic burdens (79-81). Therefore, pathways mediating the initiation of allergic airway responses have been extensively studied, and IL-33 has been indicated to be a potential target molecule for the early control and prevention of allergic airway inflammation (82-84). In the current study, the association between IL-33 and AR was demonstrated, and novel data regarding the genetic basis of AR in the Han Chinese population were analyzed. Subsequent analyses validating these findings may reveal further genetic susceptibility to AR. Moreover, GWAS are still required to determine the shared and unique mechanisms of AR compared with other atopic diseases.

\section{Acknowledgements}

Not applicable.

\section{Funding}

No funding was received.

\section{Availability of data and materials}

All data generated or analyzed during this study are included in this published article.

\section{Authors' contributions}

HR and HX conceived the present study, conducted the primary experiments and analyses. XZ, LG and SL performed additional experiments. HR and XZ collected clinical samples. HR and HX drafted the manuscript. All authors read and approved the final manuscript.

\section{Ethics approval and consent to participate}

The present study was approved by the Ethics Committees of The Second Hospital of Jingzhou, Hubei College of Chinese Medicine and Shishou People's Hospital. All investigation procedures were performed in agreement with the Declaration of Helsinki. Oral informed consent was provided by the participants or their guardians.

\section{Patient consent for publication}

Not applicable.

\section{Competing interests}

The authors declare that they have no competing interests.

\section{References}

1. Bousquet J, Khaltaev N, Cruz AA, Denburg J, Fokkens WJ, Togias A, Zuberbier T, Baena-Cagnani CE, Canonica GW, van Weel $\mathrm{C}$, et al: Allergic rhinitis and its impact on asthma (ARIA) 2008 update (in collaboration with the world health organization, GA(2)LEN and AllerGen). Allergy 63 (Suppl 86): S8-S160, 2008.

2. Leynaert B, Neukirch F, Demoly P and Bousquet J: Epidemiologic evidence for asthma and rhinitis comorbidity. J Allergy Clin Immunol 106 (5 Suppl): S201-S205, 2000.

3. Bousquet J, Van Cauwenberge P and Khaltaev N; Aria Workshop Group; World Health Organization: Allergic rhinitis and its impact on asthma. J Allergy Clin Immunol 108 (5 Suppl): S147-S334, 2001

4. Falade AG, Ige OM, Yusuf BO, Onadeko MO and Onadeko BO: Trends in the prevalence and severity of symptoms of asthma, allergic rhinoconjunctivitis, and atopic eczema. J Natl Med Assoc 101: 414-418, 2009.

5. Nathan RA: The burden of allergic rhinitis. Allergy Asthma Proc 28: 3-9, 2007.

6. Worldwide variation in prevalence of symptoms of asthma, allergic rhinoconjunctivitis, and atopic eczema: ISAAC. The international study of asthma and allergies in childhood (ISAAC) steering committee. Lancet 351: 1225-1232, 1998.

7. Haahtela T, Holgate S, Pawankar R, Akdis CA, Benjaponpitak S, Caraballo L, Demain J, Portnoy J and von Hertzen L; WAO Special Committee on Climate Change and Biodiversity: The biodiversity hypothesis and allergic disease: World allergy organization position statement. World Allergy Organ J 6: 3 , 2013.

8. Wang XD, Zheng M, Lou HF, Wang CS, Zhang Y, Bo MY, Ge SQ, Zhang N, Zhang L and Bachert C: An increased prevalence of self-reported allergic rhinitis in major Chinese cities from 2005 to 2011. Allergy 71: 1170-1180, 2016.

9. Thompson AK, Juniper E and Meltzer EO: Quality of life in patients with allergic rhinitis. Ann Allergy Asthma Immunol 85: 338-347; quiz 347-8, 2000.

10. Dunlop J, Matsui E and Sharma HP: Allergic rhinitis: Environmental determinants. Immunol Allergy Clin North Am 36: 367-377, 2016.

11. Greiner AN, Hellings PW, Rotiroti G and Scadding GK: Allergic rhinitis. Lancet 378: 2112-2122, 2011.

12. Portelli MA, Hodge E and Sayers I: Genetic risk factors for the development of allergic disease identified by genome-wide association. Clin Exp Allergy 45: 21-31, 2015.

13. Willemsen G, van Beijsterveldt TC, van Baal CG, Postma D and Boomsma DI: Heritability of self-reported asthma and allergy: A study in adult Dutch twins, siblings and parents. Twin Res Hum Genet 11: 132-142, 2008.

14. Fagnani C, Annesi-Maesano I, Brescianini S, D'Ippolito C, Medda E, Nisticò L, Patriarca V, Rotondi D, Toccaceli V and Stazi MA: Heritability and shared genetic effects of asthma and hay fever: An Italian study of young twins. Twin Res Hum Genet 11: 121-131, 2008.

15. Bunyavanich S, Schadt EE, Himes BE, Lasky-Su J, Qiu W, Lazarus R,Ziniti JP, Cohain A,Linderman M, Torgerson DG, et al: Integrated genome-wide association, coexpression network, and expression single nucleotide polymorphism analysis identifies novel pathway in allergic rhinitis. BMC Med Genomics 7: 48, 2014.

16. Andiappan AK, Wang de Y, Anantharaman R, Parate PN, Suri BK, Low HQ, Li Y, Zhao W, Castagnoli P, Liu J and Chew FT: Genome-wide association study for atopy and allergic rhinitis in a Singapore Chinese population. PLoS One 6: e19719, 2011.

17. Fujii R,Hishida A, Wu MC, Kondo T, Hattori Y,Naito M,Endoh K, Nakatochi M, Hamajima N, Kubo M, et al: Genome-wide association study for pollinosis identified two novel loci in interleukin (IL)-1B in a Japanese population. Nagoya J Med Sci 80: 109-120, 2018.

18. Shen Y, Liu Y, Wang XQ, Ke X, Kang HY and Hong SL: Association between TNFSF4 and BLK gene polymorphisms and susceptibility to allergic rhinitis. Mol Med Rep 16: 3224-3232, 2017.

19. Zhang Y, Lin X, Desrosiers M, Zhang W, Meng N, Zhao L, Han D and Zhang L: Association pattern of interleukin-1 receptor-associated kinase- 4 gene polymorphisms with allergic rhinitis in a Han Chinese population. PLoS One 6: e21769, 2011. 
20. Ke X, Song S, Wang X, Shen Y, Kang H and Hong S: Associations of single nucleotide polymorphisms of PTPN22 and Ctla4 genes with the risk of allergic rhinitis in a Chinese Han population. Hum Immunol 78: 227-231, 2017.

21. Kanazawa J, Masuko H, Yatagai Y, Sakamoto T, Yamada H Kitazawa H, Iijima H, Naito T, Saito T, Noguchi E, et al: Association analyses of eQTLs of the TYRO3 gene and allergic diseases in Japanese populations. Allergol Int 68: 77-81, 2019.

22. Ke X, Yang Y, Shen Y, Wang X and Hong S: Association between TNFAIP3 gene polymorphisms and risk of allergic rhinitis in a Chinese Han population. Iran J Allergy Asthma Immunol 15: 46-52, 2016.

23. Nilsson D, Andiappan AK, Hallden C, Tim CF, Säll T, Wang de Y and Cardell LO: Poor reproducibility of allergic rhinitis SNP associations. PLoS One 8: e53975, 2013.

24. Waage J, Standl M, Curtin JA, Jessen LE, Thorsen J, Tian C, Schoettler N; 23andMe Research Team; AAGC collaborators, Flores C, et al: Genome-wide association and HLA fine-mapping studies identify risk loci and genetic pathways underlying allergic rhinitis. Nat Genet 50: 1072-1080, 2018.

25. Li J, Zhang Y and Zhang L: Discovering susceptibility genes for allergic rhinitis and allergy using a genome-wide association study strategy. Curr Opin Allergy Clin Immunol 15: 33-40, 2015.

26. Romagnani S: The increased prevalence of allergy and the hygiene hypothesis: Missing immune deviation, reduced immune suppression, or both? Immunology 112: 352-363, 2004.

27. Romagnani S: Lymphokine production by human $\mathrm{T}$ cells in disease states. Annu Rev Immunol 12: 227-257, 1994.

28. Abbas AK, Murphy KM and Sher A: Functional diversity of helper T lymphocytes. Nature 383: 787-793, 1996.

29. Li L, Xia Y, Nguyen A, Lai YH, Feng L, Mosmann TR and Lo D: Effects of Th2 cytokines on chemokine expression in the lung: IL-13 potently induces eotaxin expression by airway epithelia cells. J Immunol 162: 2477-2487, 1999.

30. Durham SR, Ying S, Varney VA, Jacobson MR, Sudderick RM, Mackay IS, Kay AB and Hamid QA: Cytokine messenger RNA expression for IL-3, IL-4, IL-5, and granulocyte/macrophage-colony-stimulating factor in the nasal mucosa after local allergen provocation: Relationship to tissue eosinophilia. J Immunol 148: 2390-2394, 1992.

31. Bischoff SC, Sellge G, Lorentz A, Sebald W, Raab R and Manns MP: IL-4 enhances proliferation and mediator release in mature human mast cells. Proc Natl Acad Sci USA 96: 8080-8085, 1999.

32. Hardman CS, Panova V and McKenzie AN: IL-33 citrine reporter mice reveal the temporal and spatial expression of IL-33 during allergic lung inflammation. Eur J Immunol 43 : 488-498, 2013

33. Bystrom J, Patel SY, Amin K and Bishop-Bailey D: Dissecting the role of eosinophil cationic protein in upper airway disease. Curr Opin Allergy Clin Immunol 12: 18-23, 2012.

34. Prefontaine D, Nadigel J, Chouiali F, Audusseau S, Semlali A, Chakir J, Martin JG and Hamid Q: Increased IL-33 expression by epithelial cells in bronchial asthma. J Allergy Clin Immunol 125 752-754, 2010

35. Lloyd CM: IL-33 family members and asthma-bridging innate and adaptive immune responses. Curr Opin Immunol 22 : 800-806, 2010

36. Shimizu M, Matsuda A, Yanagisawa K, Hirota T, Akahoshi M Inomata N, Ebe K, Tanaka K, Sugiura H, Nakashima K, et al: Functional SNPs in the distal promoter of the ST2 gene are associated with atopic dermatitis. Hum Mol Genet 14: 2919-2927, 2005.

37. Grotenboer NS, Ketelaar ME, Koppelman GH and Nawijn MC: Decoding asthma: Translating genetic variation in IL-33 and IL1RL1 into disease pathophysiology. J Allergy Clin Immunol 131: 856-865, 2013.

38. Watanabe M, Nakamoto K, Inui T, Sada M, Honda K, Tamura M, Ogawa Y, Yokoyama T, Saraya T, Kurai D, et al: Serum sST2 levels predict severe exacerbation of asthma. Respir Res 19: 169, 2018.

39. Li R, Yang G, Yang R, Peng X and Li J: Interleukin-33 and receptor ST2 as indicators in patients with asthma: A meta-analysis. Int J Clin Exp Med 8: 14935-14943, 2015.

40. Schmitz J, Owyang A, Oldham E, Song Y, Murphy E, McClanahan TK, Zurawski G, Moshrefi M, Qin J, Li X, et al: IL-33, an interleukin-1-like cytokine that signals via the IL-1 receptor-related protein ST2 and induces T helper type 2-associated cytokines. Immunity 23: 479-490, 2005.
41. Oshikawa K, Yanagisawa K, Tominaga S and Sugiyama Y: Expression and function of the ST2 gene in a murine model of allergic airway inflammation. Clin Exp Allergy 32: 1520-1526, 2002.

42. Lohning M, Stroehmann A, Coyle AJ, Grogan JL, Lin S, Gutierrez-Ramos JC, Levinson D, Radbruch A and Kamradt T: T1/ST2 is preferentially expressed on murine Th2 cells, independent of interleukin 4, interleukin 5, and interleukin 10, and important for Th2 effector function. Proc Natl Acad Sci USA 95: 6930-6935, 1998.

43. Coyle AJ, Lloyd C, Tian J, Nguyen T, Erikkson C, Wang L, Ottoson P, Persson P, Delaney T, Lehar S, et al: Crucial role of the interleukin 1 receptor family member T1/ST2 in T helper cell type 2-mediated lung mucosal immune responses. J Exp Med 190: 895-902, 1999.

44. Xu D, Chan WL, Leung BP, Huang FP, Wheeler R, Piedrafita D, Robinson JH and Liew FY: Selective expression of a stable cell surface molecule on type 2 but not type 1 helper T cells. J Exp Med 187: 787-794, 1998.

45. Lecart S, Lecointe N, Subramaniam A, Alkan S, Ni D, Chen R, Boulay V, Pène J, Kuroiwa K, Tominaga S and Yssel H: Activated, but not resting human Th2 cells, in contrast to Th1 and T regulatory cells, produce soluble ST2 and express low levels of ST2L at the cell surface. Eur J Immunol 32: 2979-2987, 2002.

46. Trajkovic V, Sweet MJ and Xu D: T1/ST2-an IL-1 receptor-like modulator of immune responses. Cytokine Growth Factor Rev 15: 87-95, 2004

47. Ding W, Zou GL, Zhang W, Lai XN, Chen HW and Xiong LX: Interleukin-33: Its emerging role in allergic diseases. Molecules 23: 1665, 2018.

48. Haenuki Y, Matsushita K, Futatsugi-Yumikura S, Ishii KJ, Kawagoe T, Imoto Y, Fujieda S, Yasuda M, Hisa Y, Akira S, et al: A critical role of IL-33 in experimental allergic rhinitis. J Allergy Clin Immunol 130: 184-194 e11, 2012.

49. Gluck J, Rymarczyk B and Rogala B: Serum IL-33 but not ST2 level is elevated in intermittent allergic rhinitis and is a marker of the disease severity. Inflamm Res 61: 547-550, 2012.

50. Sakashita M, Yoshimoto T, Hirota T, Harada M, Okubo K, Osawa Y, Fujieda S, Nakamura Y, Yasuda K, Nakanishi K and Tamari M: Association of serum interleukin-33 level and the interleukin-33 genetic variant with Japanese cedar pollinosis. Clin Exp Allergy 38: 1875-1881, 2008.

51. Du Y, Luo Y, Yang C, Liu J, Wan J and Wang K: Discussion IL-33 and its receptor ST2 associated with the pathogenesis of allergic rhinitis. Lin Chuang Er Bi Yan Hou Tou Jing Wai Ke Za Zhi 29: 811-814, 2015 (In Chinese).

52. Guo-Zhu H, Xi-Ling Z, Zhu W, Li-Hua W, Dan H, Xiao-Mu W, Wen-Yun $\mathrm{Z}$ and Wei-Xu H: Therapeutic potential of combined anti-IL-1 $\beta$ IgY and anti-TNF- $\alpha$ IgY in guinea pigs with allergic rhinitis induced by ovalbumin. Int Immunopharmacol 25 : 155-161, 2015.

53. Asaka D, Yoshikawa M, Nakayama T, Yoshimura T, Moriyama $\mathrm{H}$ and Otori N: Elevated levels of interleukin-33 in the nasal secretions of patients with allergic rhinitis. Int Arch Allergy Immunol 158 (Suppl 1): S47-S50, 2012.

54. Kim YH, Yang TY, Park CS, Ahn SH, Son BK, Kim JH, Lim DH and Jang TY: Anti-IL-33 antibody has a therapeutic effect in a murine model of allergic rhinitis. Allergy 67: 183-190, 2012

55. Kamekura R, Kojima T, Takano K, Go M, Sawada N and Himi T: The role of IL-33 and its receptor ST2 in human nasal epithelium with allergic rhinitis. Clin Exp Allergy 42: 218-228, 2012.

56. Shaw JL, Fakhri S, Citardi MJ, Porter PC, Corry DB, Kheradmand F, Liu YJ and Luong A: IL-33-responsive innate lymphoid cells are an important source of IL-13 in chronic rhinosinusitis with nasal polyps. Am J Respir Crit Care Med 188: 432-439, 2013.

57. Soyka MB, Holzmann D, Basinski TM, Wawrzyniak M, Bannert C, Bürgler S, Akkoc T, Treis A, Rückert B, Akdis M, et al: The induction of IL-33 in the sinus epithelium and its influence on T-helper cell responses. PLoS One 10: $\mathrm{e} 0123163,2015$.

58. Baumann R, Rabaszowski M, Stenin I, Tilgner L, Gaertner-Akerboom M, Scheckenbach K, Wiltfang J, Chaker A, Schipper J and Wagenmann M: Nasal levels of soluble IL-33R ST2 and IL-16 in allergic rhinitis: Inverse correlation trends with disease severity. Clin Exp Allergy 43: 1134-1143, 2013.

59. Position paper: Allergen standardization and skin tests. The European academy of allergology and clinical immunology. Allergy 48: 48-82, 1993. 
60. 1000 Genomes Project Consortium, Auton A, Brooks LD, Durbin RM, Garrison EP, Kang HM, Korbel JO, Marchini JL, McCarthy S, McVean GA and Abecasis GR: A global reference for human genetic variation. Nature 526: 68-74, 2015.

61. Torgerson DG, Ampleford EJ, Chiu GY, Gauderman WJ, Gignoux CR, Graves PE, Himes BE, Levin AM, Mathias RA, Hancock DB, et al: Meta-analysis of genome-wide association studies of asthma in ethnically diverse North American populations. Nat Genet 43: 887-892, 2011.

62. Demenais F, Margaritte-Jeannin P, Barnes KC, Cookson WOC, Altmüller J, Ang W, Barr RG, Beaty TH, Becker AB, Beilby J, et al: Multiancestry association study identifies new asthma risk loci that colocalize with immune-cell enhancer marks. Nat Genet 50: 42-53, 2018.

63. 63.Zhu Z, Lee PH, Chaffin MD, Chung W, Loh PR, Lu Q, Christiani DC and Liang L: A genome-wide cross-trait analysis from UK Biobank highlights the shared genetic architecture of asthma and allergic diseases. Nat Genet 50: 857-864, 2018.

64. Bonnelykke K, Sleiman P, Nielsen K, Kreiner-Møller E, Mercader JM, Belgrave D, den Dekker HT, Husby A, Sevelsted A, Faura-Tellez G, et al: A genome-wide association study identifies CDHR3 as a susceptibility locus for early childhood asthma with severe exacerbations. Nat Genet 46: 51-55, 2014.

65. Barrett JC, Fry B, Maller J and Daly MJ: Haploview: Analysis and visualization of LD and haplotype maps. Bioinformatics 21 : 263-265, 2005.

66. Shi YY and He L: SHEsis, a powerful software platform for analyses of linkage disequilibrium, haplotype construction, and genetic association at polymorphism loci. Cell Res 15: 97-98, 2005

67. Li Z, Zhang Z, He Z, Tang W, Li T, Zeng Z, He L and Shi Y: A partition-ligation-combination-subdivision EM algorithm for haplotype inference with multiallelic markers: Update of the SHEsis (http://analysis.bio-x.cn). Cell Res 19: 519-523, 2009.

68. Lemonnier N, Melen E, Jiang Y, Joly S, Ménard C, Aguilar D, Acosta-Perez E, Bergström A, Boutaoui N, Bustamante M, et al: A novel whole blood gene expression signature for asthma, dermatitis, and rhinitis multimorbidity in children and adolescents. Allergy 2020 (Epub ahead of print)

69. Rogala B and Gluck J: The role of interleukin-33 in rhinitis. Curr Allergy Asthma Rep 13: 196-202, 2013.

70. Tomita K, Sakashita M, Hirota T, Tanaka S, Masuyama K, Yamada T, Fujieda S, Miyatake A, Hizawa N, Kubo M, et al: Variants in the 17q21 asthma susceptibility locus are associated with allergic rhinitis in the Japanese population. Allergy 68: 92-100, 2013

71. Li Y, Chen J, Rui X, Li N, Jiang F and Shen J: The association between sixteen genome-wide association studies-related allergic diseases loci and childhood allergic rhinitis in a Chinese Han population. Cytokine 111: 162-170, 2018.
72. Yoon D, Ban HJ, Kim YJ, Kim EJ, Kim HC, Han BG, Park JW, Hong SJ, Cho SH, Park K and Lee JS: Replication of genome-wide association studies on asthma and allergic diseases in Korean adult population. BMB Rep 45: 305-310, 2012.

73. Amarin JZ, Naffa RG, Suradi HH, Alsaket YM, Obeidat NM, Mahafza TM and Zihlif MA: An intronic single-nucleotide polymorphism (rs13217795) in FOXO3 is associated with asthma and allergic rhinitis: A case-case-control study. BMC Med Genet 18: $132,2017$.

74. Li X, Hastie AT, Hawkins GA, Moore WC, Ampleford EJ, Milosevic J, Li H, Busse WW, Erzurum SC, Kaminski N, et al: eQTL of bronchial epithelial cells and bronchial alveolar lavage deciphers GWAS-identified asthma genes. Allergy 70: 1309-1318, 2015

75. Ketelaar ME, Portelli MA, Dijk FN, Shrine N, Faiz A, Vermeulen CJ, Xu CJ, Hankinson J, Bhaker S, Henry AP, et al: Phenotypic and functional translation of IL-33 genetics in asthma. J Allergy Clin Immunol 2020 (Epub ahead of print).

76. Gorbacheva AM, Korneev KV, Kuprash DV and Mitkin NA: The risk $\mathrm{G}$ allele of the single-nucleotide polymorphism rs 928413 creates a CREB1-Binding site that activates IL-33 promoter in lung epithelial cells. Int J Mol Sci 19: 2911, 2018.

77. Paller AS, Spergel JM, Mina-Osorio P and Irvine AD: The atopic march and atopic multimorbidity: Many trajectories, many pathways. J Allergy Clin Immunol 143: 46-55, 2019.

78. Akdis CA, Arkwright PD, Bruggen MC, Busse W, Gadina M, Guttman-Yassky E, Kabashima K, Mitamura Y, Vian L, Wu J and Palomares O: Type 2 immunity in the skin and lungs. Allergy 75: $1582-1605,2020$

79. D'Amato G, Ortega OPM, Annesi-Maesano I and D'Amato M: Prevention of allergic asthma with allergen avoidance measures and the role of exposome. Curr Allergy Asthma Rep 20: 8, 2020.

80. Liccardi G, Cazzola M, Walter Canonica G, Passalacqua G and D'Amato G: New insights in allergen avoidance measures for mite and pet sensitized patients. A critical appraisal. Respir Med 99: 1363-1376, 2005.

81. Halken S: Prevention of allergic disease in childhood: Clinical and epidemiological aspects of primary and secondary allergy prevention. Pediatr Allergy Immunol 15 (Suppl 16): 4-5, 9-32, 2004.

82. Cook J and Saglani S: Pathogenesis and prevention strategies of severe asthma exacerbations in children. Curr Opin Pulm Med 22: 25-31, 2016

83. Chen WY, Tsai TH, Yang JL and Li LC: Therapeutic strategies for targeting IL-33/ST2 signalling for the treatment of inflammatory diseases. Cell Physiol Biochem 49: 349-358, 2018.

84. Takatori H, Makita S, Ito T, Matsuki A and Nakajima H: Regulatory mechanisms of IL-33-ST2-Mediated allergic inflammation. Front Immunol 9: 2004, 2018 